\title{
Role of external inputs of nutrients to aquatic ecosystems in determining prevalence of nitrogen vs. phosphorus limitation of net primary productivity
}

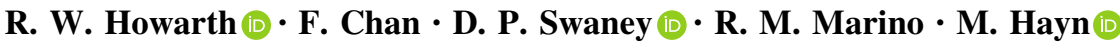

Received: 4 November 2020/Accepted: 3 February 2021/Published online: 17 February 2021

(C) The Author(s) 2021

\begin{abstract}
Whether net primary productivity in an aquatic ecosystem is limited by nitrogen $(\mathrm{N})$, limited by phosphorus $(\mathrm{P})$, or co-limited by $\mathrm{N} \& \mathrm{P}$ is determined by the relative supply of $\mathrm{N}$ and $\mathrm{P}$ to phytoplankton compared to their elemental requirements for primary production, often characterized by the "Redfield" ratio. The supply of these essential nutrients is affected by both external inputs and biogeochemical processes within the ecosystem. In this paper, we examine external sources of nutrients to
\end{abstract}

Responsible Editor: Kate Lajtha.

This paper is an invited contribution to the 35th Anniversary Special Issue, edited by Sujay Kaushal, Robert Howarth, and Kate Lajtha.

Supplementary Information The online version contains supplementary material available at https://doi.org/10.1007/ s10533-021-00765-z.

R. W. Howarth $(\bowtie) \cdot$ D. P. Swaney ·

R. M. Marino · M. Hayn

Department of Ecology \& Evolutionary Biology, Cornell

University, Ithaca, NY 14853, USA

e-mail: howarth@cornell.edu

R. W. Howarth · R. M. Marino - M. Hayn

The Ecosystems Center, Marine Biological Laboratory,

Woods Hole, MA 02543, USA

F. Chan

OSU-NOAA Cooperative Institute, Oregon State

University, Corvallis, OR 97331, USA aquatic systems and how the balance of $\mathrm{N}$ to $\mathrm{P}$ inputs influences nutrient limitation. For ocean subtropical gyres, a relatively balanced input of $\mathrm{N}$ and $\mathrm{P}$ relative to the Redfield ratio from deep ocean sources often leads to near co-limitation by $\mathrm{N}$ and $\mathrm{P}$. For lakes, the external nutrient inputs come largely from watershed sources, and we demonstrate that on average the N:P ratio for these inputs across the United States is well above that needed by phytoplankton, which may contribute to $\mathrm{P}$ limitation in those lake that experience this average nutrient loading. Watershed inputs are also important for estuaries and coastal marine ecosystems, but ocean sources of nutrients are also significant contributors to overall nutrient loads. The ocean-nutrient sources of $\mathrm{N}$ and $\mathrm{P}$ are very often at or below the Redfield ratio of 16:1 molar, and can be substantially so, particularly in areas where the continental shelf is wide. This large input of coastal ocean nutrients with a low N:P ratio is one factor that may make $\mathrm{N}$ limitation more likely in many coastal marine ecosystems than in lakes.

Keywords Nutrient limitation · Nitrogen limitation · Phosphorus limitation - Aquatic ecosystems ·

Estuaries · Coastal marine ecosystems $\cdot$ Redfield ratio · NANI $\cdot$ NAPI $\cdot$ Nutrient stoichiometry 


\section{Introduction}

Aquatic scientists have long noted major differences in nutrient control of net primary productivity across different types of ecosystems, with phosphorus (P) limitation in many lakes (Schindler 1974; Vollenweider 1975), nitrogen (N) limitation in many estuaries and coastal marine ecosystems (Ryther 1954), and co-limitation by $\mathrm{N}$ and $\mathrm{P}$ in many open ocean systems such as the subtropical gyres (Redfield 1958). Exceptions to these generalities exist, and some coastal marine ecosystems are limited by $\mathrm{P}$ rather than $\mathrm{N}$ while some lakes are limited by N (Howarth 1988; Bergström and Jansson 2006; Elser et al. 2009; Hayes et al. 2018). Time scale matters, and ecosystems can switch between $\mathrm{N}$ and $\mathrm{P}$ limitation seasonally, including both lakes and estuaries (Fisher et al. 1992; Dolman et al. 2016).

The topic of nutrient limitation in aquatic ecosystems is controversial, with long-standing debates about how one best determines which nutrient is most limiting. Our goal in this paper is not to further debate the evidence by which one determines which nutrient is more limiting, which we have previously discussed in some detail (Howarth 1988; Howarth and Marino 2006); see also NRC (2000). We agree with the suggestion of Moss et al. (2013) that limitation by a single nutrient is more likely in human-impacted, more nutrient-enriched systems, and that co-limitation by $\mathrm{N}$ and $\mathrm{P}$ is more likely in oligotrophic ecosystems (see also Begon et al. 2014). In our view, P limitation is more prevalent than $\mathrm{N}$ limitation in mesotrophic and eutrophic lakes, and $\mathrm{N}$ limitation is more prevalent in temperate-zone estuaries. Our personal research experience informs this belief, including our long-term study of a coastal marine lagoon that is clearly $\mathrm{N}$ limited (Howarth et al. 2014) and research on a lake that is clearly P limited (Peterson et al. 1974; Roberts and Howarth 2006). The coastal system, West Falmouth Harbor on Cape Cod, MA, is characterized by low dissolved inorganic $\mathrm{N}$ concentrations (generally $<$ $1 \mu \mathrm{M})$ and moderate concentrations of soluble reactive P (0.25-1 $\mu \mathrm{M}$; Hayn et al. 2014; Howarth et al. 2014). The lake, Cayuga Lake in the Finger Lakes region of central NY, is characterized by similar concentrations of soluble reactive $\mathrm{P}$ (SRP) but concentrations of dissolved inorganic $\mathrm{N}$ that are more than two magnitudes of order greater (mean value of $380 \mu \mathrm{M}$; Halfman 2017). Although the molar N:P ratio of dissolved inorganic nutrient concentrations is an imperfect indicator of nutrient limitation, particularly when near the Redfield ratio of $16: 1$ or in ecosystems where inorganic $\mathrm{N}$ and $\mathrm{P}$ are extremely low, the ratio near 1:1 in West Falmouth Harbor and the average ratio of more than 1000:1 in Cayuga Lake clearly indicate $\mathrm{N}$ and $\mathrm{P}$ limitation on primary production, respectively (NRC 2000).

The focus of this paper is to examine the role of external nutrient inputs to aquatic ecosystems as one of the factors that may tend to make primary production more likely to be limited by $\mathrm{N}, \mathrm{P}$, or both. We and others have written extensively about the role of biogeochemical processes such as $\mathrm{N}$ fixation, denitrification, and phosphorus sorption and desorption as factors that can lead more toward limitation of $\mathrm{N}$ or $\mathrm{P}$ in an aquatic ecosystem (see for example Howarth and Marino 2006 and references therein). However, the ratio of $\mathrm{N}: \mathrm{P}$ for the external nutrient inputs to the ecosystem sets the stage against which these internal biogeochemical processes can act. For example, $\mathrm{N}$ fixation by planktonic cyanobacteria can help maintain $\mathrm{P}$ limitation in lakes when the $\mathrm{N}$ deficit is relatively small (Schindler 1977; Flett et al. 1980; Schindler et al. 2008). But in lakes where the N:P ratio of external inputs is sufficiently low, $\mathrm{N}$ fixation may not be able to make up the $\mathrm{N}$ deficit compared to $\mathrm{P}$ availability, and $\mathrm{N}$ limitation can occur (Moss et al. 2013; Grantz et al. 2014; Hayes et al. 2018). Significant planktonic $\mathrm{N}$ fixation is largely absent from saline estuaries, which is one of the reasons we believe coastal marine ecosystems are more likely than lakes to be $\mathrm{N}$ limited (Howarth et al. 1988; Marino et al. 2002; Marino and Howarth 2016).

For the surface waters of much of the world's oceans away from shore and continental shelves, including the subtropical gyres that cover half of the area of the oceans and $35 \%$ of the total surface of the Earth, the largest source of nutrient inputs by far is mixing of deeper ocean waters across the thermocline (Michaels et al. 1996). The mixing rate is low, but the nutrient content of this water is quite high, so the input to the surface oceans is substantial. As we present below, the ratio of $\mathrm{N}$ to $\mathrm{P}$ in these deep waters is quite close to the Redfield ratio (Karl et al. 1997; Michaels et al. 1996). This leads to co-limitation of net primary productivity by both nutrients in the subtropical gyres, consistent with the thought that co-limitation by $\mathrm{N}$ and $\mathrm{P}$ may be the norm in oligotrophic ecosystems (Begon 
et al. 2014). This balance between $\mathrm{N}$ and $\mathrm{P}$ cycling in open ocean waters is at the center of the Redfield (1958) concept.

Most lakes receive the vast majority of their nutrient inputs from their watersheds, although atmospheric inputs of both $\mathrm{N}$ and $\mathrm{P}$ can be important, particularly in lakes with relatively pristine landscapes and consequently small rates of watershed loading. Estuaries and coastal marine ecosystems also receive substantial inputs of nutrients from watersheds and atmospheric deposition, but they additionally receive inputs of nutrients from ocean sources (Nixon et al. 1996; Howarth et al. 2011). This major difference in the external nutrient sources between lakes and coastal marine systems often escapes attention and is one of the major foci of this paper. In this paper, we first explore the average inputs of nutrients to aquatic ecosystems from their watersheds in the context of the United States, using a mass balance modeling approach at the regional scale, and then we examine dissolved $\mathrm{N}$ and $\mathrm{P}$ data from across the global oceans as sources of nutrients to the coastal zone.

Since this paper is an invited contribution for the special issue of Biogeochemistry celebrating more than 35 years of the journal, we note that the watershed nutrient inputs we discuss next are based on our 1996 paper published in Biogeochemistry as part of another earlier special issue (Howarth et al. 1996). This paper won the John Martin ASLO award in 2018 in recognition of being a highly influential paper. The 1996 special issue focused on papers developing an $\mathrm{N}$ budget for the North Atlantic Ocean as part of the International SCOPE Nitrogen Project. Other papers from that issue (Nixon et al. 1996; Michaels et al. 1996; Seitzinger and Giblin 1996) are also central to the development of the logic behind this current paper.

\section{Nutrient inputs from the landscape}

The rate of nutrient loading from the landscape to lakes and estuaries has been estimated for thousands of systems globally. However, there is no uniformly accepted methodology for estimating $\mathrm{N}$ and $\mathrm{P}$ loading (NRC 2000), complicating comparisons across systems. Here, we build on our previous work and use a regional nutrient accounting approach to estimate the average $\mathrm{N}$ and $\mathrm{P}$ loads from watersheds across the
United States by region and over time, presenting 5-year averages from 1987 to 2012. The approach is based on the Net Anthropogenic Nitrogen Inputs (NANI) and Net Anthropogenic Phosphorus Inputs (NAPI) to the landscape (Howarth et al. 1996, 2006, 2012; Hong et al. 2011, 2012, 2013; Han et al. 2011).

NANI is the sum of $\mathrm{N}$ inputs to a region from synthetic $\mathrm{N}$ fertilizer, $\mathrm{N}$ fixation by agricultural crops, atmospheric deposition of $\mathrm{N}$, and the $\mathrm{N}$ in food and feed for humans and livestock. If there is a net export of $\mathrm{N}$ in food and feed, this is treated as a negative input and is subtracted from the other inputs (Howarth et al. 1996; Hong et al. 2011). The approach for NAPI is very similar, but the net import of $\mathrm{P}$ in detergents and other non-food uses is included, and atmospheric deposition of $\mathrm{P}$ is assumed to be negligible (Han et al. 2011; Hong et al. 2012). We present data for several large regions of the United States based on countyscale data (Fig. 1a). As of the writing of this manuscript, county-scale data for fertilizer sales after 2012 are still not available from the USDA agricultural census (Slater, AAPFCO, pers. comm.).

The input terms for NAPI are as described in Swaney and Howarth (2019). For NANI, the input terms are as described in Swaney et al. (2018) except for $\mathrm{N}$ deposition. In our previously published work, atmospheric $\mathrm{N}$ deposition estimates for NANI were based on the U.S. Environmental Protection Agency CMAQ model. Here, we use updated estimates of atmospheric $\mathrm{N}$ deposition from a hybrid approach now favored by the US EPA (Schwede and Lear 2014), combining CMAQ output with National Atmospheric Deposition Program observational data to make deposition estimates (NADP 2018). The refinement to the approach shows lower values of $\mathrm{NO}_{\mathrm{y}}$ deposition for 2012 than our previous estimates (Howarth et al. 2012; Hong et al. 2013), consistent with observed declines in emissions (Butler et al. 2011).

Net Anthropogenic Nitrogen Inputs per watershed area are the highest in the Mid-Atlantic region but are also high in California, the Great Lakes area, the Mississippi River basin, and the South Atlantic/Gulf Coast (Fig. 1b). Values are considerably lower in New England, the Pacific Northwest, and the Texas Gulf coast area. In all of the regions, changes in NANI over time have been relatively small, sometimes increasing and sometimes decreasing. Net Anthropogenic Phosphorus Inputs per area of watershed are highest in the 
(a)

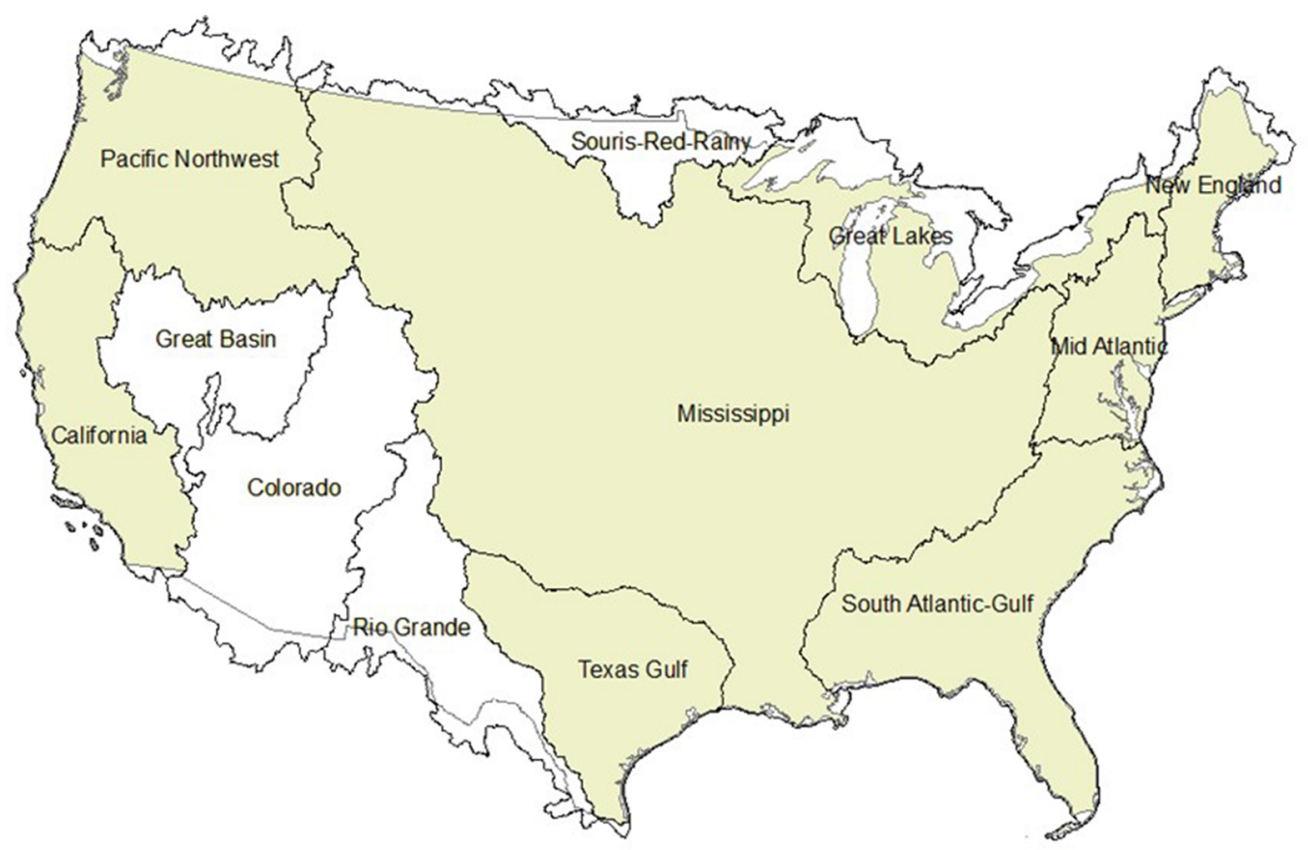

(b)

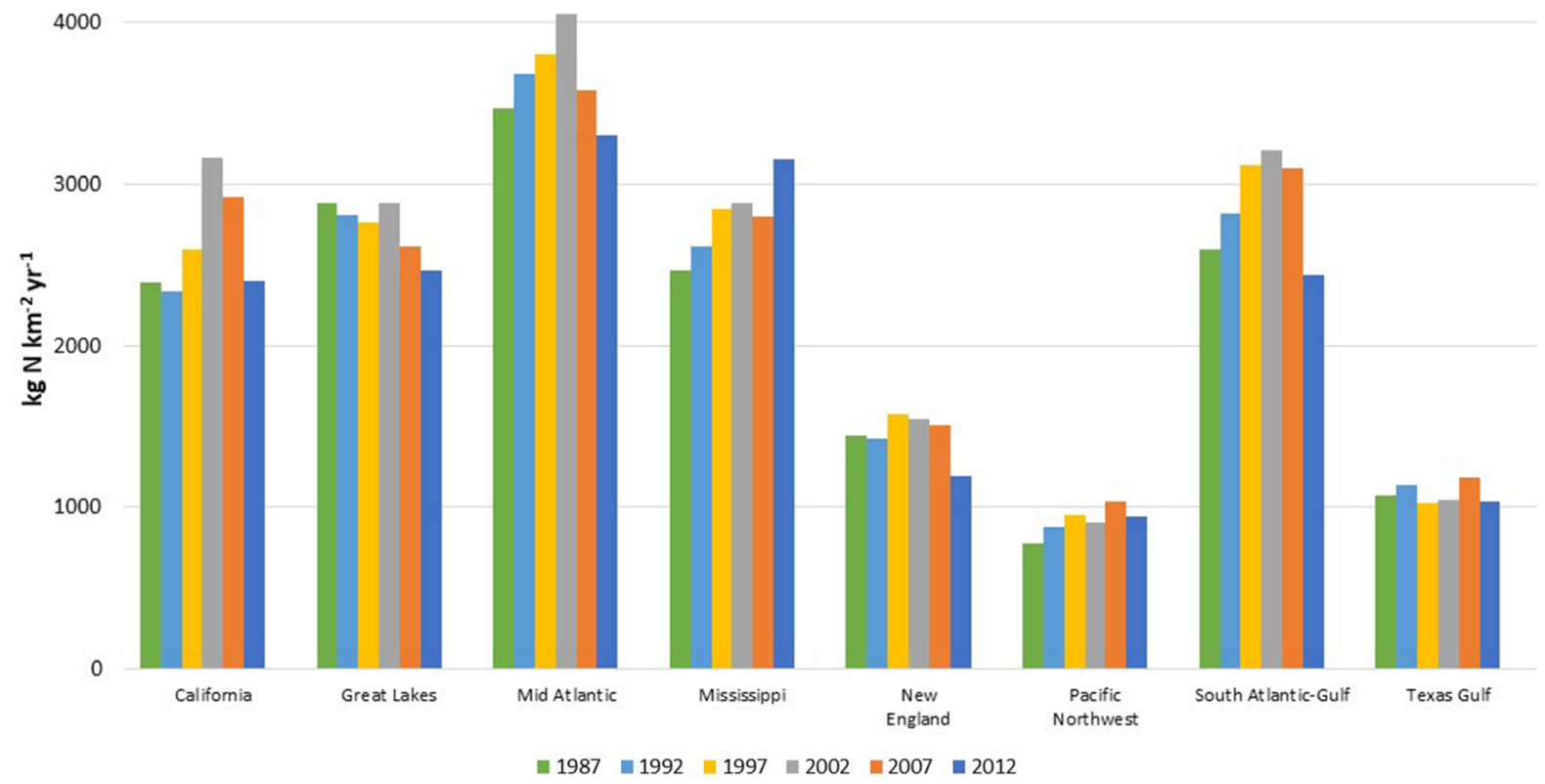

Fig. 1 a Regions of the United States for which we report data on NANI and NAPI. b NANI for each major region of the United States over time from 1987 to 2017. c NAPI for each major region of the United States over time from 1987 to 2017.

Mid-Atlantic and South Atlantic/Gulf Coast regions, and are far lower in most other regions, particularly New England and the Pacific Northwest (Fig. 1c). As d Molar ratio of nitrogen to phosphorus exported from each major region of the United States over time from 1987 to 2017. The Redfield ratio of 16:1 is shown as a dashed red line for context

with NANI, time trends for NAPI over time have been relatively small, with the exception of the Great Lakes region which saw a steady decline from 1987 to 2012 . 
(c) 1000

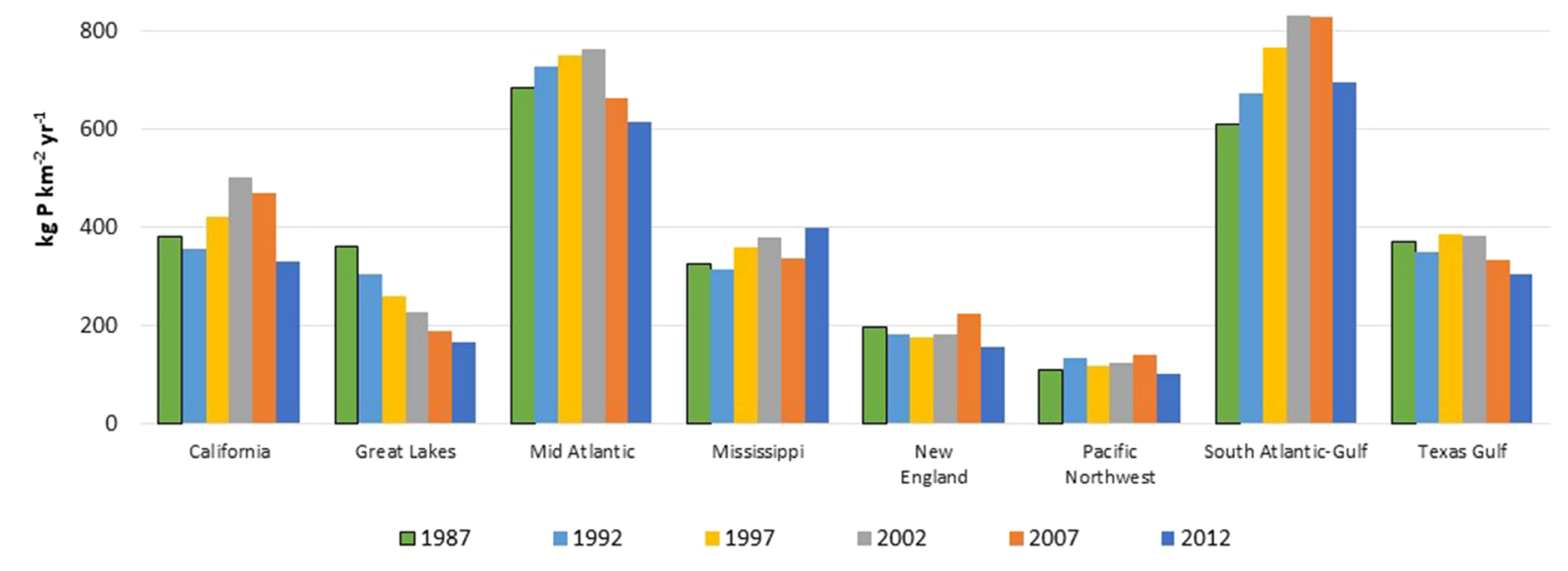

(d)

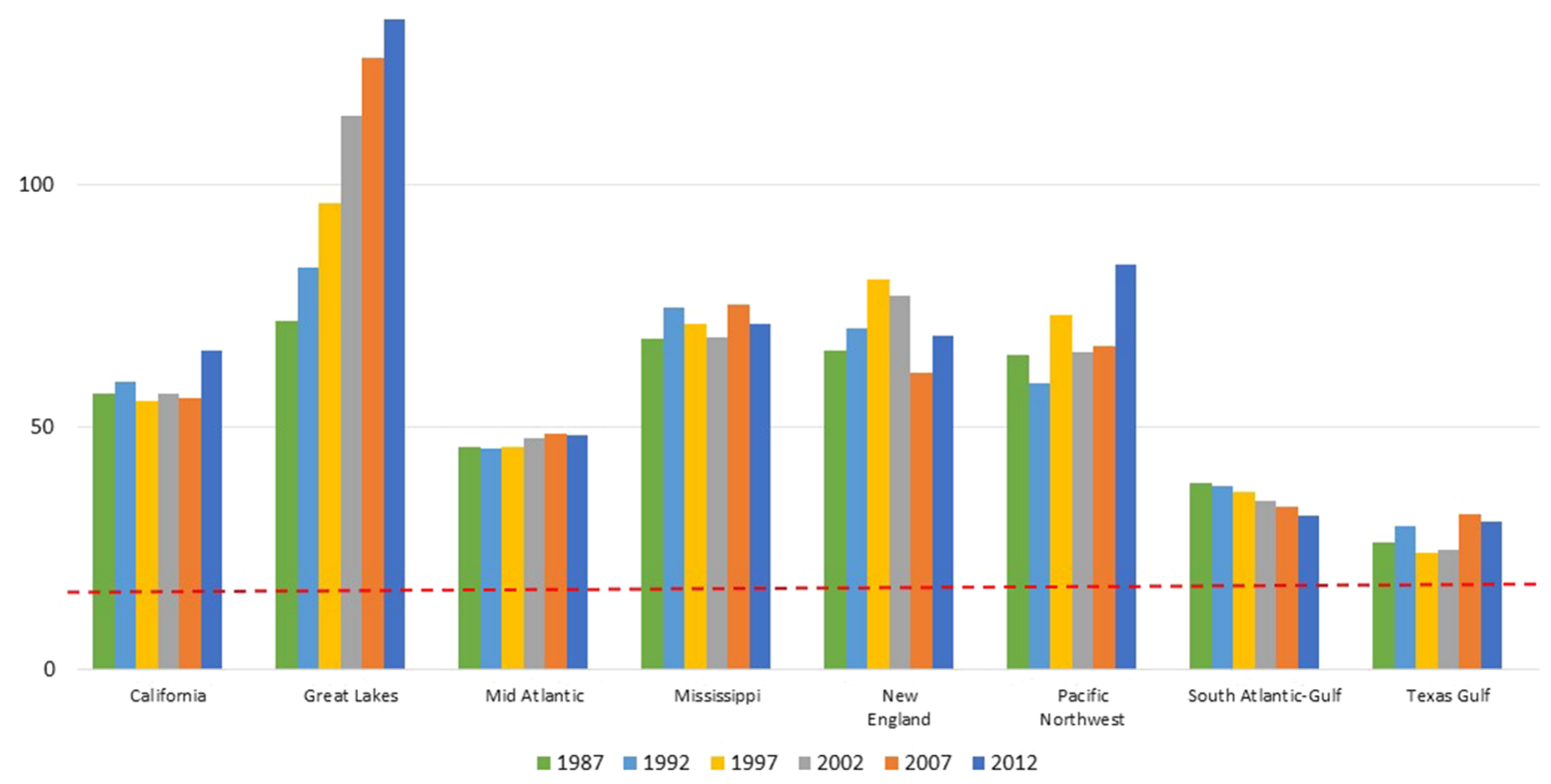

Fig. 1 continued

To examine the ratio of total $\mathrm{N}$ to total $\mathrm{P}$ likely exported from each region to aquatic ecosystems, we first calculate the portions of NANI and NAPI that move downstream. For NANI, an average of $24 \%$ is exported from large watersheds as total $\mathrm{N}$, based on a data set for 154 watersheds in the United States, Europe, and the United Kingdom (Howarth et al. 2012; Hong et al. 2013). Note that this is virtually identical to the $26 \%$ export of NANI that we estimated from the analysis of large regions in our original NANI paper (Howarth et al. 1996). While there is some variation in the percentage of NANI that is exported across these watersheds, it is relatively small. Surprisingly, the variation does not seem tied to the specific $\mathrm{N}$ inputs, the intensity of agriculture, topography, soil types, or other such factors (Howarth et al. 1996, 2012; Hong et al. 2013). Most of the differences in export across regions are related to climate, with greater percentage exports in regions where precipitation and river discharge per area are higher. For simplicity in 
this paper, we use the average export of 24\%. Most of the $\mathrm{N}$ that is not exported downstream is denitrified or stored in the watershed (van Breemen et al. 2002).

For NAPI, we assume that $5.9 \%$ is exported downstream as total P. This is the average observed for 57 moderately large watersheds in the United States (Zhang et al. 2015). Somewhat lower export percentages are observed in China (2.9\%) and Europe (3.9\%), and Zhang et al. (2015) report an overall average export of $3.4 \%$ for 158 watersheds in the United States, China, and Europe. For this paper, we are using the $5.9 \%$ value since we are considering only regions in the United States. We recognize that this may bias our $\mathrm{P}$ export numbers towards the high end.

Using NANI and NAPI export percentages of $24 \%$ and $5.9 \%$ respectively, we can calculate the molar N:P ratio of nutrients leaving each region of the United States over time (Fig. 1d). In all regions and at all times since 1987 this N:P ratio is high, well above the Redfield ratio of 16:1. As we state in the paragraph above, our $\mathrm{P}$ export values may be biased high, and if that is the case and actual $P$ fluxes are less than we estimate, the N:P ratios shown in Fig. 1d would be even higher. The N:P ratios of exports from the landscape are particularly high in the Great Lakes, the Mississippi River basin, New England, and the Pacific Northwest, ranging from somewhat $>50: 1$ to well over 100:1. The N:P ratio is lowest in the Texas Gulf region. Changes in the $\mathrm{N}: \mathrm{P}$ ratio of exported nutrients over time have been small in most regions, but the Great Lakes region saw a large increase in this N:P ratio from 1987 to 2012 (Fig. 1d), largely driven by the decrease in NAPI in this region over time (Fig. 1c).

There is some debate over when and if nutrients stored in the landscape ("legacy nutrients") are ultimately released, thereby enriching receiving waters, and how significant this is as a proportion of total nutrient loading. Some modeling efforts suggest current nutrient loads are due in part to release of legacy nutrients (Van Meter et al. 2017; McCrackin et al. 2018). However, these legacy nutrient sources are ultimately the result of excess NANI and NAPI storage in the landscape, and are not an additional input to the system. Van Meter et al. (2017) suggest that current nutrient exports have a larger proportion of legacy $\mathrm{N}$ than legacy $\mathrm{P}$, indicating that using the long-term average export proportions as in the calculation above would produce a conservative estimate of
$\mathrm{N}$ relative to $\mathrm{P}$, and the $\mathrm{N}: \mathrm{P}$ ratio could be somewhat higher.

It is important to reiterate that NANI and NAPI have several input terms and generally are not driven by any particular term such as fertilizer use (Howarth et al. 1996, 2012; Hong et al. 2011, 2012). This is illustrated by contrasting two different regions, New England and the Mississippi River basin. For NANI in New England, the biggest input terms are atmospheric deposition and net import of food and animal feeds, with fertilizer use and $\mathrm{N}$ fixation by agricultural crops being considerably smaller (Fig. 2a). On the other hand, the largest $\mathrm{N}$ inputs in the Mississippi River basin are from fertilizer use and agricultural $\mathrm{N}$ fixation. Further, the food and animal feeds term is negative in the Mississippi River basin, indicating a net export rather than an import, as in New England. In fact, more $\mathrm{N}$ leaves the Mississippi River basin via export of food and feed than flows down the Mississippi River (Fig. 2a). In both New England and the Mississippi River basin, it is NANI that determines riverine $\mathrm{N}$ flows, not any single input term. For NAPI, fertilizer is the largest input for both New England and the Mississippi River basin, followed by import in food and feeds (Fig. 2b). While the import of P in food and feeds in the Mississippi River basin is small, it is a positive value on average, in contrast to the net export of $\mathrm{N}$ from the basin. Mean values of the input terms for NANI and NAPI for the 1987-2012 period for each of the regions are shown in tables in on-line only supplemental material.

The regional-scale watershed fluxes we estimate are for total $\mathrm{N}$ and total $\mathrm{P}$. Not all of this $\mathrm{N}$ and $\mathrm{P}$ will be biologically available to primary producer organisms in recipient ecosystems. Of the organic $\mathrm{N}$ and $\mathrm{P}$, some will be mineralized to readily available forms on ecologically meaningful time scales, but some will simply be buried and not become available, particularly for total N (Howarth et al. 1996; Nixon et al. 1996). It is important to note that as human activity increases overall nutrient loads, inorganic $\mathrm{N}$ and $\mathrm{P}$ increasingly come to dominate total $\mathrm{N}$ and $\mathrm{P}$ fluxes (Meybeck 1982; Howarth et al. 1996; Seitzinger et al. 2005). All of the inorganic $N$ that enters an aquatic ecosystem remains biologically available, but for inorganic $\mathrm{P}$, much can be adsorbed to soil and sediment particles. Some of this may become available in recipient ecosystems but some will not. Adsorbed $\mathrm{P}$ is much more likely to desorb and become 


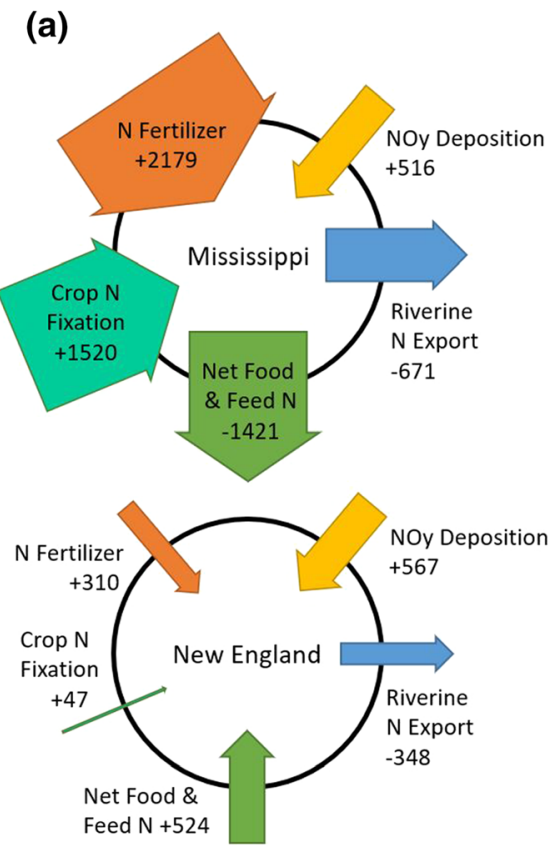

Fig. 2 a Comparison on input terms for NANI in New England (bottom) and the Mississippi River basin (top) in $\mathrm{kg} \mathrm{N}$ per square kilometer per year. Also shown are exports of $\mathrm{N}$ in water flowing to coastal ecosystems based on $24 \%$ of NANI. See text.

biologically available in estuaries and coastal marine ecosystems than in lakes, due to higher ionic strength and more ions competing for sorption sites as salinity increases (Froelich 1988; Howarth et al. 1995).

\section{Influence of watershed loads on $\mathrm{N}$ vs $\mathrm{P}$ limitation}

For lakes, those that receive nutrient loads from their watershed with an $\mathrm{N}: \mathrm{P}$ molar ratio for total nutrients above the relative $\mathrm{N}$ and $\mathrm{P}$ requirements of phytoplankton would be expected to be P-limited, unless biogeochemical processes within the lake decrease the availability of $\mathrm{N}$ relative to $\mathrm{P}$, lowering the $\mathrm{N}: \mathrm{P}$ ratio for available nutrients below that needed by the primary producers. Of course, processes within the lake can lower the ratio of available N:P, for instance if denitrification rates are greater than rates of $\mathrm{N}$ fixation. The rates of biogeochemical processes that control $\mathrm{N}$ and $\mathrm{P}$ availabilities vary as a function of lake size, water residence time, and other factors (Moss et al. 2013; They et al. 2017). Nonetheless, the watershed nutrient inputs set the stage for the relative availability of $\mathrm{N}$ and $\mathrm{P}$ that support primary production. (b)
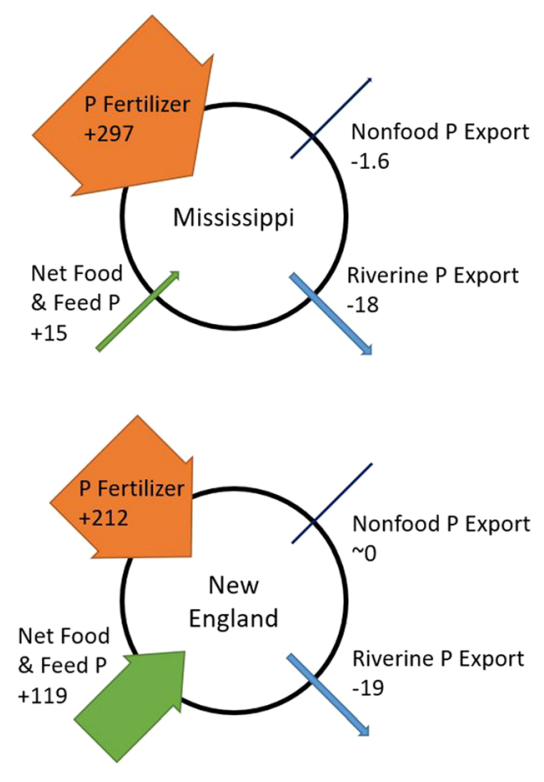

b Comparison on input terms for NAPI in New England (bottom) and the Mississippi River basin (top) in $\mathrm{kg}$ P per square kilometer per year. Also shown are exports of $\mathrm{P}$ in water flowing to coastal ecosystems based on $5.9 \%$ of NAPI. See text

What are the relative requirements of $\mathrm{N}$ and $\mathrm{P}$ for algae and cyanobacteria? Redfield (1958) originally proposed that marine phytoplankton need $\mathrm{N}$ and $\mathrm{P}$ in a 16:1 molar ratio. There is some plasticity in this ratio for $\mathrm{N}: \mathrm{P}$ needs across different primary producers, both in the oceans and in lakes (Hecky and Kilham 1988; Karl et al. 1997). Limnologists often use the N:P ratio of seston to infer whether a lake is more limited by $\mathrm{N}$ or P (Hecky and Kilham 1988; Dolman et al. 2016), although it is difficult to tease apart how much of the sestonic particulate $\mathrm{N}$ and $\mathrm{P}$ is in living phytoplankton vs detritus, including that of terrestrial origin. Nonetheless, the N:P ratio of seston in lakes, while generally $>16: 1$, is low compared to the loading ratios we show in Fig. 1d, ranging from 17:1 to $39: 1$ in a variety of lakes, with a mean of 23:1 for small lakes and 26:1 for large lakes (Sterner et al. 2008).

The high N:P loading ratios shown in Fig. 1d would be expected to lead toward a tendency for P limitation in the receiving waterbodies, particularly considering that much of the particle-adsorbed P may not become available in a lake. This is consistent with the widespread prevalence of $\mathrm{P}$ limitation of net primary productivity across many North American lakes 
(Vollenweider 1975). We want to emphasize, though, that lakes undoubtedly vary greatly in the N:P ratio of their nutrient inputs, and no individual lake receives the average $\mathrm{N}$ and $\mathrm{P}$ loads indicated by this regional approach based on NANI and NAPI. Combined with biogeochemical processes within lakes that can alter $\mathrm{N}$ and $\mathrm{P}$ availability, it should come as no surprise that many lakes are $\mathrm{N}$ limited. Lakes in catchments that are totally forested will have lower total loads of both $\mathrm{N}$ and $\mathrm{P}$, with no inputs from agricultural sources; in regions where atmospheric $\mathrm{N}$ deposition is low, lakes in forested catchments are often oligotrophic and $\mathrm{N}$ limited or co-limited by $\mathrm{N}$ and $\mathrm{P}$, but high deposition rates over time can shift the $\mathrm{N}: \mathrm{P}$ stoichiometry, leading to P limitation (Bergström and Jansson 2006; Elser et al. 2009). Note further than even lakes in largely forested catchments may have inputs of both $\mathrm{N}$ and $\mathrm{P}$ related to the food and feed term of NANI and NAPI, for instance due to nutrient inputs from onsite wastewater treatment systems from nearby homes.

This same construct of the N:P ratio for external nutrient inputs setting the stage for limitation of primary production by $\mathrm{N}$ vs $\mathrm{P}$ also should apply to estuaries and coastal marine ecosystems: unless internal biogeochemical processes are sufficient to compensate, nutrient inputs from the watershed with an $\mathrm{N}: \mathrm{P}$ ratio substantially above the needs of the phytoplankton would be expected to lead to $\mathrm{P}$ limitation. The N:P ratios shown in Fig. 1d are far above the Redfield ratio of $16: 1$ or the seston $\mathrm{N}: \mathrm{P}$ ratios commonly found in marine ecosystems, which tend to be below 20:1 in coastal waters and productive areas and range between 15:1 and 28:1 in oligotrophic ocean systems (Karl et al. 1997; Sterner et al. 2008; Martiny et al. 2013). Why then is $\mathrm{N}$ limitation commonly observed in most coastal marine ecosystems, in sharp contrast to so many lakes (Howarth and Marino 2006)? Part of the answer undoubtedly lies in the differences between the relative influence of the biogeochemical processes that occur within coastal ecosystems compared to lakes. These differences include a lack of planktonic $\mathrm{N}$ fixation in saline estuaries (Howarth et al. 1988; Marino et al. 2002; Marino and Howarth 2016) and the desorption of $\mathrm{P}$ from particles as salinity increases in an estuary (Froelich 1988; Howarth et al. 1995). Another important part of the answer, although one less discussed in the literature, is the $\mathrm{N}: \mathrm{P}$ ratio of external inputs to the ecosystem: many estuaries and other coastal marine systems receive a significant portion of their nutrient inputs from ocean sources, not just from their watersheds.

\section{Nutrient inputs from ocean sources}

In many cases, oceanic inputs to estuaries are not measured and are not included in nutrient budgets (as discussed by Nixon et al. 1996). However, just as salt from coastal ocean systems is mixed and advected up into an estuary, nutrients from these coastal waters are also transported. Nutrient inputs from the ocean can be substantial, particularly for $\mathrm{P}$, as can be seen for coastal systems with datasets rich enough to make good estimates. For example, an estimated $24 \%$ of the $\mathrm{P}$ inputs to Chesapeake Bay and $36 \%$ of $\mathrm{P}$ inputs to the Potomac River estuary come from ocean sources, with virtually no input of $\mathrm{N}$ from the ocean to these systems (Boynton et al. 1995). For both the Changjiang River estuary (Li et al. 2011) and the heavily N-loaded West Falmouth Harbor (Hayn et al. 2014; Howarth et al. 2014), P inputs from the ocean source are sufficient to maintain $\mathrm{N}$ limitation. In both of these systems, $\mathrm{P}$ inputs were proportionally greater than $\mathrm{N}$ inputs relative to the Redfield ratio of 16:1.

Figure 3 shows molar N:P ratios for inorganic nutrients (as nitrate + nitrite and SRP) in the deep waters below the thermocline for the world's oceans from the World Ocean Atlas 2018 (WOA18; Garcia et al. 2018). Values represent observations from the deepest bins within each $1^{\circ}$ gridded cell. We present data on inorganic $\mathrm{N}$ and SRP, rather than total $\mathrm{N}$ and $\mathrm{P}$ as we did for the watershed loading estimates, simply because inorganic data are common and total $\mathrm{N}$ and $\mathrm{P}$ data rare in oceanographic studies and data bases. Note, though, that in deep ocean waters, concentrations of inorganic $\mathrm{N}$ and SRP are very high and greatly dominate both the total $\mathrm{N}$ and total $\mathrm{P}$ pools (Michaels et al. 1996). For most of the world's oceans, bottom waters have molar $\mathrm{N}: \mathrm{P}$ ratios near the Redfield ratio of 16:1. Mixing of these deep-ocean waters into the surface waters of the subtropical gyres provides $\mathrm{N}$ and $P$ in a ratio very near the Redfield ratio, so it should not be surprising that these open ocean systems are nearly co-limited by $\mathrm{N}$ and $\mathrm{P}$, as originally described by Redfield (1958). On the other hand, the N:P ratio in the bottom waters near the coast are often well below the Redfield ratio (Fig. 3). The flux of nutrients from these 


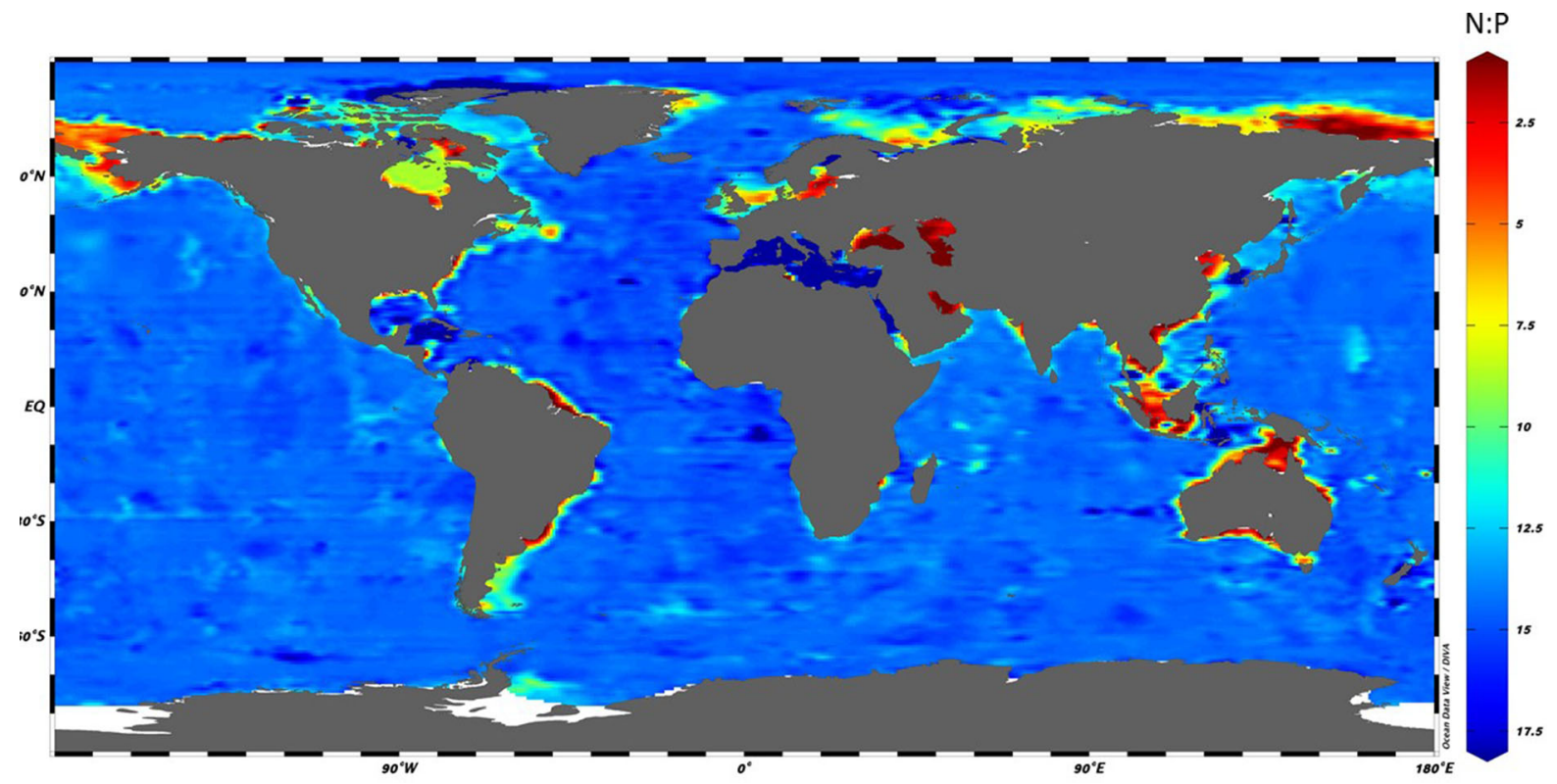

Fig. 3 Molar ratio of nitrate + nitrite to SRP in the bottom waters of the world's oceans

near-bottom waters which are depleted in $\mathrm{N}$ relative to $\mathrm{P}$ would thus help maintain the deficits of inorganic $\mathrm{N}$ in coastal waters that flow into estuaries. The advection of dissolved materials into an estuary from coastal waters with low N:P ratios will import relatively more $\mathrm{P}$ and strengthen the likelihood of persistent $\mathrm{N}$-limitation.

We observe that the $\mathrm{N}: \mathrm{P}$ ratio for inorganic nutrients of bottom waters often appears to be lower along coasts that have a substantial continental shelf, such as the East and Gulf coasts of the United States, the European coast of the North Sea, and the coast of China (Fig. 3). Much of the research on nutrient limitation in estuaries has occurred in these areas, where $\mathrm{N}$ limitation has been found to be so common. Interestingly, oligotrophic lagoons along the French Mediterranean coast are $\mathrm{P}$ limited (Souchu et al. 2010), and the nearby bottom waters in the Mediterranean Sea have a very high N:P ratio for inorganic nutrients compared to most ocean regions (Fig. 3).

To further examine the effects of continental shelf biogeochemical processes in structuring $\mathrm{N}$ and $\mathrm{P}$ inputs to estuaries, we plot the inorganic nutrient concentrations for surface waters on the continental shelves of the United States as a function of the width of the continental shelf at the sampling site. Since the $1^{\circ}$ resolution of the WOA18 can conflate shelf and open ocean observations, we used the GLobal Ocean
Data Analysis Project (GLODAP) database (Olsen et al. 2016) which offers highly quality-controlled observations from precise sampling locations. The data are for individual samples from cruises over many years and are snapshots in time, not longer-term mean values.

For both nitrate + nitrite (Fig. 4a) and SRP (Fig. 4b), concentrations are quite variable in locations where the continental shelves are narrow. For areas where the shelf is less than $30 \mathrm{~km}$ wide, nitrate + nitrite varies from 0 to $33 \mu \mathrm{mol} \mathrm{kg}^{-1}$ and SRP varies from 0 to $2.4 \mu \mathrm{mol} \mathrm{kg}{ }^{-1}$. In areas where the continental shelves are wider, concentrations of nitrate + nitrite and of SRP are not as high as sometimes observed at sites on the narrower shelves. For sites from areas where the shelf is wider than $100 \mathrm{~km}$, nitrate + nitrite concentrations are generally at or near $0 \mu \mathrm{mol} \mathrm{kg} \mathrm{kg}^{-1}$ (Fig. 4a), while SRP concentrations are $<0.5 \mu \mathrm{mol} \mathrm{kg}{ }^{-1}$ (Fig. 4b). These low concentrations for nitrate + nitrite and SRP reflect both uptake by phytoplankton and net exchanges with sediments. The shallower water depths of the continental shelves can encourage phytoplankton blooms, with concomitant drawdown of both nitrate + nitrite and SRP. Further, the sediments on continental shelves are the major site both for burial of $\mathrm{P}$ (Ruttenberg and Berner 1993; Howarth et al. 1995) and of denitrification (Falkowski 1997; Galloway et al. 2004) globally 

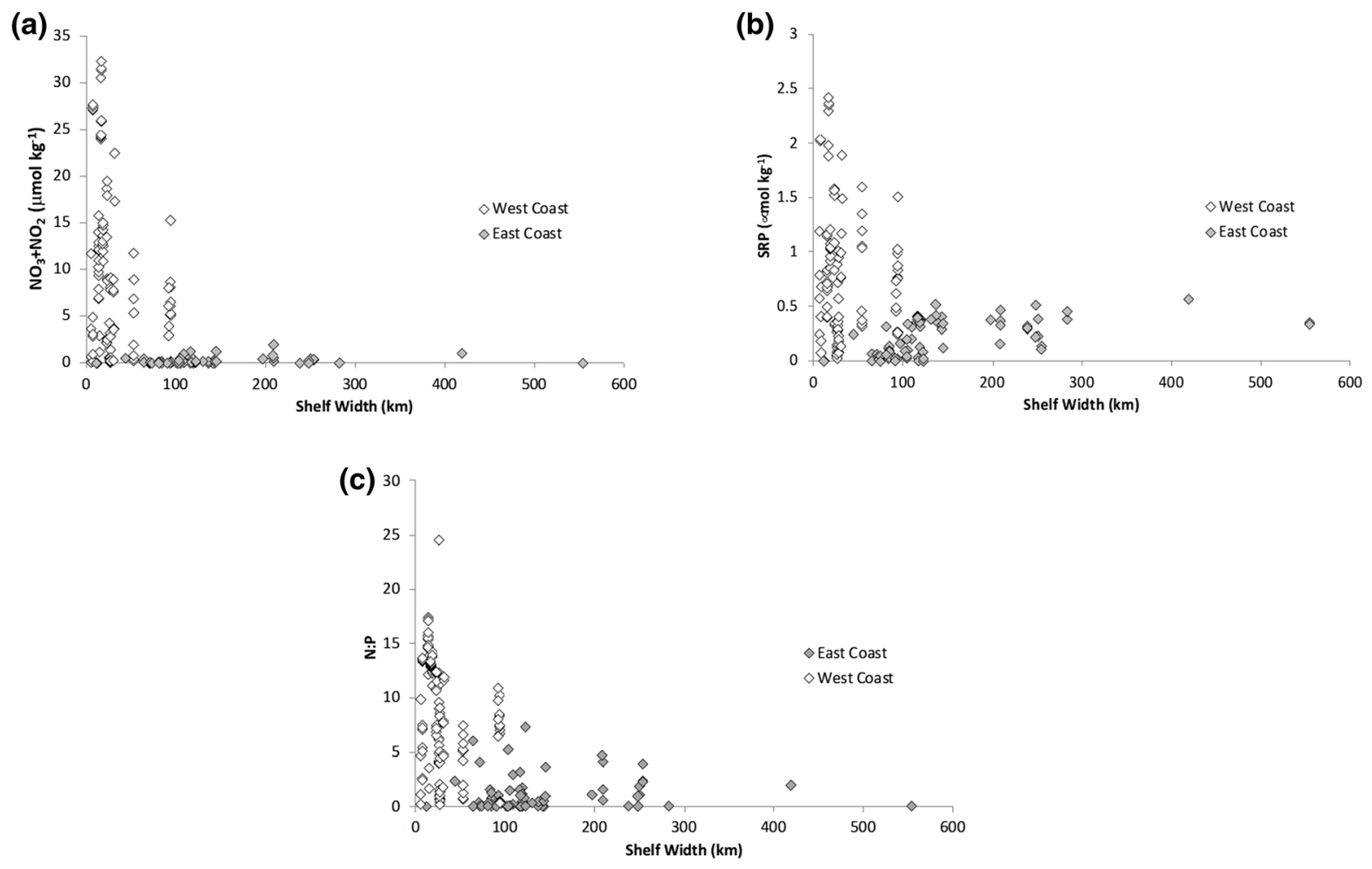

Fig. 4 a Nitrate + nitrite concentration in surface waters for sites on the continental shelves of the United States plotted as a function of the width of the shelf at that site. East coast and west coast shown separately. b SRP concentration in surface waters for sites on the continental shelves of the United States plotted as

in the world's oceans. Denitrification can have a substantial influence on the inorganic $\mathrm{N}$ availability in regions where the continental shelf is wide. For example, denitrification on the continental shelf along the east coast of the United States and Canada is estimated to be the major N sink there (Seitzinger and Giblin 1996; Fennel et al. 2006).

The magnitude as well as the relative importance of deep-ocean nutrient inputs onto the continental shelves can vary from region to region. All along the east coast of the United States and Canada, the advection of deep-ocean, nutrient-rich waters is the largest supply of nutrients to the shelves (Nixon et al. 1996; Michaels et al. 1996; Howarth et al. 1996; Howarth 1998). For example, the continental shelf along the northeastern United States from Maine south through Delaware receives $75 \%$ of its $\mathrm{N}$ inputs from the deep-ocean source, $1.54 \mathrm{Tg} \mathrm{N}_{\text {year }}{ }^{-1}$ compared to only $0.27 \mathrm{Tg} \mathrm{N}$ year $^{-1}$ from watershed sources and $0.21 \mathrm{Tg} \mathrm{N}_{\mathrm{gear}}{ }^{-1}$ from direct atmospheric deposition a function of the width of the shelf at that site. East coast and west coast shown separately. c Molar ratio of nitrate + nitrite to SRP in surface waters for sites on the continental shelves of the United States plotted as a function of the width of the shelf at that site. East coast and west coast shown separately

(Howarth 1998). In other regions, the deep-ocean nutrient source can be less important. The northern Gulf of Mexico receives only $5 \%$ of its nitrogen from the deep ocean, $0.14 \mathrm{Tg} \mathrm{N}_{\text {year }}{ }^{-1}$ compared to $2.1 \mathrm{Tg}$ $\mathrm{N}$ year ${ }^{-1}$ from the Mississippi River basin and $0.28 \mathrm{Tg}$ $\mathrm{N}$ year $^{-1}$ from direct atmospheric deposition (Howarth 1998).

The input of nutrients from the ocean (continental shelf) source is only one factor that determines overall nutrient availability and limitation in an estuary, but in many cases, this ocean-sourced water can be substantial and may contain proportionately more SRP than nitrate + nitrite, resulting in low N:P ratios (Fig. 4c). This is an important driver that can counterbalance the higher $\mathrm{N}: \mathrm{P}$ ratio inputs from watersheds, and which may therefore make $\mathrm{N}$ limitation more likely in many estuaries than in lakes. Based on this factor, we suspect that $\mathrm{N}$ limitation is more likely in estuaries near a wide continental shelf in close proximity to deep-ocean waters, such as the East Coast of the United States or 
the North Sea, than those near a narrow continental shelf such as the west coast of the United States.

We want to emphasize that the data in Figs. 3, 4a-c are for inorganic $\mathrm{N}$ and SRP, not total $\mathrm{N}$ and $\mathrm{P}$. In deep ocean waters, organic $\mathrm{N}$ and $\mathrm{P}$ are small compared to inorganic $\mathrm{N}$ and $\mathrm{P}$ (Michaels et al. 1996), but this is less true in surface waters or on the continental shelves, where inorganic $\mathrm{N}$ and SRP concentrations are lower. In a qualitative sense, we believe the inorganic data well represent the patterns of relative availabilities of $\mathrm{N}$ and $\mathrm{P}$ as sources of nutrients to surface waters and estuaries. If dissolved inorganic $\mathrm{N}$ remains low compared to SRP in the waters entering an estuary, it suggests a disproportionately high input of available P. Nonetheless, we urge more emphasis on patterns and fluxes of total $\mathrm{N}$ and $\mathrm{P}$ in future studies, with routine measurement of total $\mathrm{N}$ and $\mathrm{P}$ by oceanographers working at continental shelf sites as well as by estuarine scientists, and more interaction of biogeochemists with physical oceanographers in estimating total $\mathrm{N}$ and $\mathrm{P}$ fluxes in ecosystem budgets.

\section{Concluding thoughts and suggested future research}

Whether an estuary or other coastal marine ecosystem is $\mathrm{N}$ or $\mathrm{P}$ limited will be determined by the balance of $\mathrm{N}$ and $\mathrm{P}$ inputs from land, of $\mathrm{N}$ and $\mathrm{P}$ inputs from ocean sources, and of biogeochemical processes within the ecosystem that alter the availability of $\mathrm{N}$ and $\mathrm{P}$. We suggest that the nutrient inputs from the deep ocean onto the continental shelf and into the coastal ocean and estuaries may be much more important in the overall balance than generally recognized, and we encourage more effort in characterizing these inputs and including them in ecosystem-scale $\mathrm{N}$ and $\mathrm{P}$ budgets. Further, whether primary productivity in any specific estuary is more limited by $\mathrm{N}$ or $\mathrm{P}$ should be evaluated with consideration of coastal ocean inputs, specifically considering the $\mathrm{N}: \mathrm{P}$ ratio of the coastal waters and how these vary among regions partially due to differences in the width of the continental shelves and the rate of advection of deep-ocean waters onto the shelves.

As noted above, nutrient budgets for coastal marine ecosystems typically do not include the ocean source (Nixon et al. 1996). Of some of the previous efforts that did include ocean inputs in the nutrient budgets of coastal systems, such as the LOICZ project in the 1990s and 2000s, only dissolved inorganic nutrients were considered and not total $\mathrm{N}$ and $\mathrm{P}$ (Crossland et al. 2005; Swaney et al. 2011). There is great value in examining patterns of inorganic $\mathrm{N}$ and $\mathrm{P}$ in estuaries and other coastal marine ecosystems. For example, it is from these patterns for inorganic nutrients that $\mathrm{Li}$ et al. (2011) were able to infer the importance of the ocean source of $\mathrm{P}$ for maintaining $\mathrm{N}$ limitation in the Changjiang River estuary. However, we suggest that future ecosystem-scale budgets concentrate on fluxes of total $\mathrm{N}$ and total P, as NANI and NAPI do for watershed fluxes. This facilitates the construction of mass balances and also acknowledges that organic forms of $\mathrm{N}$ and $\mathrm{P}$ can be recycled and become available to primary producers within the ecosystem on ecologically meaningful time scales.

The input of nutrients from coastal ocean waters into an estuary depends strongly on the physics of the estuary, as this controls the rate of upstream advection. All else being equal, the upstream advection is higher in systems that have a greater tidal amplitude, but the rate of freshwater discharge into the estuary is also important. We hypothesize that an estuary can be oligotrophic only in cases where not only are watershed inputs of nutrients low but the advection into the system from coastal waters is also low, as in the microtidal lagoons along the French Mediterranean coast (Souchu et al. 2010). The corollary is that estuaries such as those along the New England coast would have been naturally mesotrophic before European settlement (with concomitant increase in the watershed nutrient load) simply because of the large tidal inputs of nutrients into these systems from ocean sources. While the nutrient inputs to pristine lakes will almost always be very low, this is not the case for many estuaries because of the ocean-source nutrients. As a generality, we would expect primary production in pristine estuaries to be greater than in pristine lakes.

Our analysis suggests that the width of the continental shelf may be one important factor regulating inorganic $\mathrm{N}$ and $\mathrm{P}$ concentrations as well as the $\mathrm{N}: \mathrm{P}$ ratio of inorganic nutrients in water advected into estuaries and shallow coastal systems. However, the rate of advection of deep ocean water onto the continental shelf, the water residence time on the shelf, and the rate of advection of water and nutrients across the shelf to an estuary all seem likely to be important drivers controlling the nutrient inputs to 
individual systems. We therefore urge more collaborative studies between coastal oceanographers and estuarine biogeochemists, to evaluate how these factors affect the nutrient inputs to an estuary. In this context, we again suggest that both patterns of inorganic nutrients and fluxes of total $\mathrm{N}$ and $\mathrm{P}$ be considered.

Finally, human-caused climate change has already altered circulation of the world's oceans, including near the continents (Doney et al. 2012; Rahmstorf et al. 2015). We hypothesize that changes in these oceanographic dynamics may alter the ocean source of nutrients to estuaries, and we speculate that such changes may already be occurring. As an example from our long-term study site, the $\mathrm{P}$ concentrations in the water entering West Falmouth Harbor from the coastal waters of Buzzards Bay now appear to be lower than a decade or so ago, both for SRP and total P (Hayn et al., manuscript in preparation). The total $\mathrm{N}$ concentration in Buzzards Bay also appears to be lower now than observed a decade ago. This may reflect less advection of deep ocean water onto the continental shelf south of Cape Cod or a longer residence time of the water on this shelf, leading to lower concentrations of $\mathrm{N}$ and $\mathrm{P}$.

Acknowledgements Preparation of this manuscript was supported by a National Science Foundation Grant \# 1654845 from the Long Term Research in Environmental Biology program, a grant from the Atkinson Center for a Sustainable Future at Cornell University, and by an endowment given to Cornell by David R. Atkinson to support a professorship held by RWH. We thank Kate Lajtha and Sujay Kaushal for inviting this submission. We also thank three anonymous peer reviewers for their very helpful comments.

Open Access This article is licensed under a Creative Commons Attribution 4.0 International License, which permits use, sharing, adaptation, distribution and reproduction in any medium or format, as long as you give appropriate credit to the original author(s) and the source, provide a link to the Creative Commons licence, and indicate if changes were made. The images or other third party material in this article are included in the article's Creative Commons licence, unless indicated otherwise in a credit line to the material. If material is not included in the article's Creative Commons licence and your intended use is not permitted by statutory regulation or exceeds the permitted use, you will need to obtain permission directly from the copyright holder. To view a copy of this licence, visit http://creativecommons.org/licenses/by/4.0/.

Author contributions RH developed the outline for the paper and wrote the first draft. FC pulled together the data on ocean sources of nutrients and wrote the related text for the first draft. DS produced the data on trends of NANI and NAPI in space and time and wrote the supplemental material. $\mathrm{RM}$ and $\mathrm{MH}$ contributed the data on changes in total $\mathrm{P}$ and $\mathrm{N}$ in Buzzards Bay over time and contributed significantly to writing the manuscript.

\section{References}

Begon M, Howarth RW, Townsend CR (2014) Essential of ecology, 4th edn. Wiley, Hoboken

Bergström A-K, Jansson M (2006) Atmospheric nitrogen deposition has caused nitrogen enrichment and eutrophication of lakes in the northern hemisphere. Glob Chang Biol 12:635-643

Boynton WR, Garber JH, Summers R, Kemp WM (1995) Inputs, transformations, and transport of nitrogen and phosphorus in Chesapeake Bay and selected tributaries. Estuaries 18:285-314

Butler T, Vermeylen FM, Rury R, Likens GE, Lee B, Bowker GE, McClune L (2011) Response of ozone and nitrate to stationary source NOx emission reductions in the eastern USA. Atmos Environ 45:1084-1094

Crossland CJ, Kremer HH, Lindeboom H, Crossland JM, Le Tissier MD (eds) (2005) Coastal fluxes in the Anthropocene: the land-ocean interactions in the coastal zone project of the International Geosphere-Biosphere Programme. Springer, Berlin

Dolman AM, Mischke U, Wiedner C (2016) Lake-type-specific seasonal patterns of nutrient limitation in German lakes, with target nitrogen and phosphorus concentrations for good ecological status. Freshw Biol 61:444-456

Doney SC, Ruckelshaus M, Duffy JE, Barry JP, Chan F, English CA, Galindo HM, Grebmeier JM, Hollowed AB, Knowlton N, Polovian J, Rabalais NN, Sydeman WJ, Talle LD (2012) Climate change impacts on marine ecosystems. Annu Rev Mar Sci 4:11-37

Elser JJ, Andersen T, Baron JS, Bergstrom A, Jansson M, Kyle M, Nydic KR, Steger L, Hessen DO (2009) Shifts in lake $\mathrm{N}: \mathrm{P}$ stoichiometry and nutrient limitation driven by atmospheric nitrogen deposition. Science 326:835-837

Falkowski PG (1997) Evolution of the nitrogen cycle and its influence on the biological sequestration of $\mathrm{CO}_{2}$ in the ocean. Nature 387:272-275

Fennel K, Wilkin J, Levin J et al (2006) Nitrogen cycling in the Middle Atlantic Bight: results from a three-dimensional model and implications for the North Atlantic nitrogen budget. Glob Biogeochem Cycles 20:GB002456. https:// doi.org/10.1029/2005GB002456

Fisher TR, Peele ER, Ammerman JW, Harding LW (1992) Nutrient limitation of phytoplankton in Chesapeake Bay. Mar Ecol Prog Ser 82:51-63

Flett RJ, Schindler DW, Hamilton RD, Campbell NER (1980) Nitrogen fixation in Canadian Precambrian Shield lakes. Can J Fish Aquat Sci 37:494-505

Froelich PN (1988) Kinetic control of dissolved phosphate in natural rivers and estuaries: a primer on the phosphate buffer mechanism. Limnol Oceanogr 33:649-668 
Galloway JN, Dentener FJ, Capone DG, Boyer EW, Howarth RW, Seitzinger SP, Asner GP, Cleveland C, Green PA, Holland E, Karl DM, Michaels A, Porter JH, Townsend A, Vorosmarty C (2004) Nitrogen cycles: past, present, and future. Biogeochemistry 70:153-226

Garcia HE, Weathers K, Paver CR, Smolyar I, Boyer TP, Locarnini RA, Zweng MM, Mishonov AV, Baranova OK, Seidov D, Reagan JR (2018) World ocean Atlas 2018, Volume 4: dissolved inorganic nutrients (phosphate, nitrate and nitrate+nitrite, silicate). Mishonov A (technical ed.), NOAA Atlas NESDIS 84, 35 pp

Grantz EM, Haggard BE, Scott JT (2014) Stoichiometric imbalance in rates of nitrogen and phosphorus retention, storage, and recycling can perpetuate nitrogen deficiency in highly-productive reservoirs. Limnol Oceanogr 59:2203-2216

Halfman JD (2017) Water quality of the eight eastern Finger Lakes, New York: 2005-2016. Finger Lakes Institute, Hobart and William Smith Colleges, Geneva

Han H, Bosch N, Allan JD (2011) Spatial and temporal variation in phosphorus budgets for 24 watersheds in the Lake Erie and Lake Michigan basins. Biogeochemistry 102:45-58

Hayes N, Patoine A, Haig H, Simpson GL, Swarbrick V, Wiik E, Leavitt PR (2018) Spatial and temporal variation in nitrogen fixation and its importance to phytoplankton in phosphorus-rich lakes. Freshw Biol 2018:1-15

Hayn M, Howarth RW, Marino R, Ganju N, Berg P, Foreman K, Giblin AE, McGlathery K (2014) Exchange of nitrogen and phosphorus between a shallow lagoon and coastal waters. Estuaries Coasts 37:63-73

Hong B, Swaney D, Howarth RW (2011) A toolbox for calculating net anthropogenic nitrogen inputs (NANI). Environ Model Softw 26:623-633

Hong B, Swaney DP, Mörth C, Smedberg E, Hägg HE, Humborg C, Howarth RW, Bouraoui F (2012) Evaluating regional variation of net anthropogenic nitrogen and phosphorus inputs (NANI/NAPI), major drivers, nutrient retention pattern and management implications in the multinational areas of Baltic Sea basin. Ecol Model 227:117-135

Hong B, Swaney DP, Howarth RW (2013) Estimating net anthropogenic nitrogen inputs (NANI) to US watersheds: comparison of methodologies. Environ Sci Technol 47:5199-5207

Howarth RW (1988) Nutrient limitation of net primary production in marine ecosystems. Annu Rev Ecol Syst 19:89-110

Howarth RW (1998) An assessment of human influences on inputs of nitrogen to the estuaries and continental shelves of the North Atlantic Ocean. Nutr Cycl Agroecosyst 52:213-223

Howarth RW, Marino RM (2006) Nitrogen as the limiting nutrient for eutrophication in coastal marine ecosystems: evolving views over 3 decades. Limnol Oceanogr 51:364-376

Howarth RW, Marino RM, Lane J, Cole JJ (1988) Nitrogen fixation in freshwater, estuarine, and marine ecosystems. 1. Rates and importance. Limnol Oceanogr 33:669-687

Howarth RW, Jensen H, Marino RM, Postma H (1995) Transport to and processing of phosphorus in near-shore and oceanic waters. In: Tiessen $\mathrm{H}$ (ed) Phosphorus in the global environment, SCOPE \#54. Wiley, Chichester, pp 323-345

Howarth RW, Billen G, Swaney D, Townsend A, Jaworski N, Lajtha K, Downing JA, Elmgren R, Caraco N, Jordan T, Berendse F, Freney J, Kueyarov V, Murdoch P, Zhao-liang Z (1996) Riverine inputs of nitrogen to the North Atlantic Ocean: fluxes and human influences. Biogeochemistry 35:75-139

Howarth RW, Boyer EW, Marino R, Swaney D, Jaworski N, Goodale C (2006) The influence of climate on average nitrogen export from large watersheds in the northeastern United States. Biogeochemistry 79:163-186

Howarth RW, Billen G, Chan F, Conley D, Doney SC, Garnier J, Marino R (2011) Coupled biogeochemical cycles: eutrophication and hypoxia in coastal marine ecosystems. Front Ecol Environ 9:18-26

Howarth RW, Swaney D, Billen G, Garnier J, Hong B, Humborg C, Johnes P, Mörth C, Marino R (2012) Nitrogen fluxes from large watershed to coastal ecosystems controlled by net anthropogenic nitrogen inputs and climate. Front Ecol Environ 10:37-43

Howarth RW, Hayn M, Marino RM, Ganju N, Foreman K, McGlathery K, Giblin AE, Berg P, Walker J (2014) Metabolism of a nitrogen-enriched coastal marine lagoon during the summertime. Biogeochemistry 118:1-20

Hecky R, Kilham P (1988) Nutrient limitation of phytoplankton production in freshwater and marine environments: a review of recent evidence on the effects of enrichment. Limnol Oceanogr 33:796-822

Karl D, Letelier R, Tupas L, Dore J, Christian J, Hebel D (1997) The role of nitrogen fixation in biogeochemical cycling in the suptropical North Pacific Ocean. Nature 388:533-538

Li XA, Yu Z, Song X, Cao X, Yuan Y (2011) Nitrogen and phosphorus budgets of the Changjiang River estuary. Chin J Oceanol Limnol 29:762-774

Marino RM, Howarth RW (2016) Why is planktonic nitrogen fixation so rare in coastal marine ecosystems? Insights from a cross-systems approach. In: Glibert P, Kana T (eds) Aquatic nutrient biogeochemistry and microbial ecology: a dual perspective. Springer, Dordrecht, pp 127-139

Marino RM, Chan F, Howarth RW, Pace M, Likens GE (2002) Ecological and biogeochemical interactions constrain planktonic nitrogen fixation in estuaries. Ecosystems 5:719-725

Martiny AC, Pham CTA, Primeau FW, Vrugt JA, Moore JK, Levin SA, Lomas WM (2013) Strong latitudinal patterns in the elemental ratios of marine plankton and organic matter. Nat Geosci 6:279-283

McCrackin ML, Muller-Karulis B, Gustafsson BG, Howarth RW, Humborg C, Svanbäck A, Swaney DP (2018) A century of legacy phosphorus dynamics in a large drainage basin. Glob Biogeochem Cycles 32:1107-1122

Meybeck M (1982) Carbon, nitrogen, and phosphorus transport by world rivers. Am J Sci 282:401-450

Michaels AF, Olson D, Sarmiento JL, Ammerman JW, Fanning K, Jahnke R, Knap AH, Lipschultz F, Prospero JM (1996) Inputs, losses and transformations of nitrogen and phosphorus in the pelagic North Atlantic Ocean. Biogeochemistry 35:181-226

Moss B, Jeppesen E, Sondergaard M, Lauridsen TL, Liu Z (2013) Nitrogen, macrophytes, shallow lakes and nutrient 
limitation: resolution of a current controversy? Hydrobiologia 710:3-21

NADP (2018) Total deposition estimates using a hybrid approach with modeled and monitoring data (documentation file for atmospheric deposition maps). National Atmospheric Deposition Program. ftp://newftp.epa.gov/ castnet/tdep/Total_Deposition_Documentation_current. pdf. Last accessed 29 Oct 2020

Nixon SW, Ammerman JW, Atkinson LP, Berounsky VM, Billen G, Boicourt WC, Boynton WR, Church TM, Ditoro DM, Elmgren R, Garber JH, Giblin AE, Jahnke RA, Owens NJP, Pilson MEQ, Seitzinger SP (1996) The fate of nitrogen and phosphorus at the land-sea margin of the North Atlantic Ocean. Biogeochemistry 35:141-180

NRC (National Research Council) (2000) Clean coastal waters: understanding and reducing the effects of nutrient pollution. National Academies Press, Washington, DC

Olsen A, Key RM, van Heuven S, Lauvset SK, Velo A, Lin X, Schirnick C, Kozyr A, Tanhua T, Hoppema M, Jutterström S, Steinfeldt R, Jeansson E, Ishii M, Pérez FF, Suzuki T (2016) The Global Ocean Data Analysis Project version 2 (GLODAPv2) - an internally consistent data product for the world ocean. Earth Syst Sci Data 8:297-323

Peterson BJ, Barlow JP, Szjage AE (1974) The physiological state with respect to phosphorus of Cayuga Lake phytoplankton. Limnol Oceanogr 19:396-408

Rahmstorf S, Box JE, Feulner G, Mann ME, Robinson A, Rutherford S, Schaffernicht EJ (2015) Exceptional twentieth-century slowdown in Atlantic Ocean overturning circulation. Nat Clim Chang 5:475-480

Redfield AC (1958) The biological control of chemical factors in the environment. Am Sci 46:205-221

Roberts BJ, Howarth RW (2006) Nutrient and light availability regulate the relative contribution of autotrophs and heterotrophs to respiration in freshwater pelagic ecosystems. Limnol Oceanogr 51:288-295

Ruttenberg K, Berner RA (1993) Authigenic apatite formation and burial in sediments from non-upwelling, continental margin environments. Geochim Cosmochim Acta 57:991-1007

Ryther JH (1954) The ecology of phytoplankton blooms in Moriches Bay and Great South Bay, Long Island, New York. Biol Bull 106:198-209

Schindler DW (1974) Eutrophication and recovery in experimental lakes: implications for lake management. Science 184:897-899

Schindler DW (1977) Evolution of phosphorus limitation in lakes. Science 195:260-262

Schindler DW, Hecky RE, Findlay DL et al (2008) Eutrophication of lakes cannot be controlled by reducing nitrogen input: results of a 37-year whole-ecosystem experiment. Proc Natl Acad Sci 105:11254-11258

Schwede DB, Lear GG (2014) A novel hybrid approach for estimating total deposition in the United States. Atmos Environ 92:207-220

Seitzinger S, Giblin A (1996) Estimating denitrification in North Atlantic continental shelf sediments. Biogeochemistry $35: 235-260$
Seitzinger S, Harrison JA, Dumon E, Beusen AHW, Bouwman AF (2005) Sources and delivery of carbon, nitrogen, and phosphorus to the coastal zone: an overview of Global Nutrient Export from Watersheds (NEWS) models and their application. Glob Biogeochem Cycles 19:1-11

Souchu P, Bec B, Smith VH, Laugier T, Fiandrino A, Benau L, Orsoni V, Collos Y, Vaquer A (2010) Patterns in nutrient limitation and chlorophyll a along an anthropogenic eutrophication gradient in French Mediterranean coastal lagoons. Can J Fish Aquat Sci 67:743-753

Sterner RW, Anderson T, Elser JJ, Hessen DO, Hood JM, McCauley E, Urabe J (2008) Scale-dependent carbon:nitrogen:phosphorus stoichiometry in marine and freshwaters. Limnol Oceanogr 53:1169-1180

Swaney DP, Howarth RW (2019) Phosphorus use efficiency and crop production: patterns of regional variation in the United States, 1987-2012. Sci Total Environ 685:174-188

Swaney DP, Smith SV, Wulff F (2011) The LOICZ biogeochemical modeling protocol and its application to estuarine ecosystems, Chapter 9.08. In: Wolanski E, McLusky D (eds) Treatise on estuarine and coastal science. Academic Press, Waltham, pp 135-159

Swaney DP, Howarth RW, Hong B (2018) Nitrogen use efficiency and crop production: patterns of regional variation in the United States, 1987-2012. Sci Total Environ 635:498-511

They NH, Amado AM, Cotner JB (2017) Redfield ratios in inland waters: higher biological control of $\mathrm{C}: \mathrm{N}: \mathrm{P}$ ratios in tropical semi-arid high water residence time lakes. Front Microbiol 8:1505

USDA National Agricultural Statistics Service (2017) NASSQuick Stats. USDA National Agricultural Statistics Service. https://data.nal.usda.gov/dataset/nass-quick-stats. Last accessed 14 Oct 2020

Van Breemen N, Boyer EW, Goodale C, Jaworski NA, Paustian K, Seitzinger SS, Lajtha K, Mayer B, van Dam D, Howarth RW, Nadelhoffer KJ, Eve M, Billen G (2002) Where did all the nitrogen go? Fate of nitrogen inputs to large watersheds in the northeastern USA. Biogeochemistry 57 \& 58:267-293

Van Meter KJ, Basu NB, Van Cappellen P (2017) Two centuries of nitrogen dynamics: legacy sources and sinks in the Mississippi and Susquehanna River Basins. Glob Biogeochem Cycles 31:2-23

Vollenweider RA (1975) Input-output models. Schweiz Z Hydrol 37:53-84

Zhang WS, Swaney DP, Hong B, Howarth RW, Han H, Li X (2015) Net anthropogenic phosphorus inputs and riverine phosphorus fluxes in highly populated headwater watersheds in China. Biogeochemistry 126:269-283

Publisher's Note Springer Nature remains neutral with regard to jurisdictional claims in published maps and institutional affiliations. 